\title{
OДФРЕСКЕ ДО СТРИПА
}

\section{Сликарско-антрополошки увиди}

Фреска - и у Ласкоу, и у Алтамири, на стени је фреска први је човеков архетипски буквар. С обзиром на миленијумску народну неписменост, слике на зиду су ондашњем човеку, данас свакако недораслом нашем времену, била „улаз кроз златна врата” у скривени свет душе.

Данас наши најмлађи, као весници још већег прогреса који нас у развоју људске врсте очекује, сигурно јесу заинтересовани и за оне архетипске слике до којих конвенционалним путем не могу доћи. Та пречица је стрип! Остаје нам само да поставимо знак математичке еквиваленције између ових двеју парадигми: фреска и стрип! Тако различити и далеки, а тако близу! У добу информатике и нанотехнологија ова начелна неподударност није немогућа. Напротив.

\section{Извор Праслике}

Андре Малро (André Malraux), говорећи о култури, каже да мозак и интелигенција, ма како означавали највиши биолошки облик тог квалитета баш код човека (мозак и интелигенцију, као карактеристику врсте, имају и многе животиње) нису оно по чему коначно разликујемо квалитет звани човек од осталог квалитета. Као и многи други, и Малро сматра да је култура та којом се човек коначно одвојио од осталих живих бића и да култура представља настанак и нарастање свег богатства око и са човеком, али пре свега нарастање самога човека. ${ }^{1}$

\footnotetext{
1 Мораћемо, ипак, да приметимо да човек, упркос сопственој великој жељи и потреби за таквим статусом, није врхунац развоја земаљског живог света, већ само „саплеменик” са свим другим живим бићима, укључујући и амебе, бактерије, зглавкаре, мраве, сисаре и остали живи свет. У супротном, уколико је човек „циљ” Творца, ови испод његовог биолошког савршенства не би постојали, јер - човек је крајњи циљ. Човек би, по таквом најегоистичнијем схватању, као врхунско биће, једини постоjaо. Колико би цивилизација због таквог сиромаштва живог света била осиромашена, не бисмо смели ни да замислимо.
} 
Култура је процес. Култура је човеков развојни пут којим искорачује изван својих нагона, почев од промискуитета и дивљаштва, од тотема и анимизма, од палеолитске уметности, од облутка и облице ка точку као једној од њему важних тачака ослонца и, потом, уређенијим друштвеним, државним и, као резултату удруживања са окружењем и све веће зависности од њега, политичким (политика = нужни интерес) односима са околином са којом се све више идентификује и везује и без које не може као појединац да опстане. Креће се постепено ка монотеистичким религијама и уметности Новог века, ка напредним и усавршенијим знањима и направама које лако прихвата и које препознајемо данас кроз аутомобиле и авионе, ракете и компјутере, нуклеарна постројења, генетски инжењеринг, информационе и нанонауке и технологије.

$$
\text { A cympa...? }
$$

Богатство културе, оно које нас је и одредило као врсту у односу на мноштво других, потиче само из једног, јединог извора - наше различитости у односу на друге врсте, али и различитости у односу између сваке јединке унутар људске врсте. $^{2}$

Ма колико да ових неколико уводних назнака, без обзира како их разуме, прихвати или одбаци свачији ум који их прочита, делују као фраза у ма којем облику, она је - изворно посматрајући, тешко подложна суштинској негацији.

Није човек култура. Култура (и некултура) је дело које човек оставља иза себе. Култура је дело које је потекло из дубине срца, а никако оно нешто што потиче и дотиче из умне жеље човека да остави нешто од себе потомству за корист (овде смо, чини се, већ на прагу не-културе, као кључне категорије ума).

Морамо се око нечега ипак разумети: ум, као први који наступа иза емоција (и нагона), није далеко испред њих, ма колико до данас (над)умне делатности човека непрекидно давале резултате. Ти резултати најмање су последица везе емоција-ум, а највише (мада то тешко прихватамо) везе ум-интуиција. Интуиција, још увек дубоко скривена испод безбројних велова наталожених током стотина и стотина

2 Ко је заслужан, или одговоран, за ову хијерархију или устројство у нама видљивом и разумљивом свету, сада се нећемо бавити. Делом због очигледности, а још више због наше индивидуалне несавршености у односу на Творца, односно творачку енергију која је све саздала, а коју ми само наслућујемо и пратимо је у, највишем домету, интуитивно. Мање или више доследно. 
хиљада година људске и земаљске цивилизације, још увек је бескрајно далеко изван рационалног домашаја данашњег људског ума... Зашто? Зато што период (тренутак!) у коме ми данас пребивамо није циљ коме је до сада тежила свеукупна цивилизација, већ један космички трептај универзума, који ми, због своје несавршености, покушавамо себично да прогласимо за циљни, или нешто слично. Човек би овде могао бескрајно много да научи од мрава, или, још боље, од пчела! Мрав је синоним за истрајност, кротост и дисциплиновано колективно постизање грандиозних корак-по-корак циљева, а пчеле су једина жива бића која су до данас, вољом Творца, добиле задатак да нам својим мрављим трудом подаре производ из ове наше баште у којој живимо, а који је најсавршенији органски производ за који се зна: мед. Имамо за то и доказе: мед из ћупова закопаних некада давно, а ископани недавно, данас има исте карактеристике и јестивост као и пре неколико хиљада година, када је и створен. Није ли то путоказ да се око нас још увек налазе сви савршени материјали, технологије и рецепти, али не знамо још како да их најлакше откријемо и најбоље употребимо.

Цивилизација и култура имају дубину која се очима не да сагледати и докучити. Човек има, упрошћено гледајући према томе, три примарне димензије. Прва је емоционална (чулна), друга је умна (разумна), а трећа, још увек већини недокучива, јесте духовна димензија (метадимензија, димензија срца, како би то малобројни узвишени духови из прве свакоме од нас спочитали).

Пошто ум реагује и везује се најчешће за опажајне и емоционалне вредности, духовна димензија човека је оно што појединцу миленијумима измиче. Већина се брзо умори од овог трагања, ако се уопште упусти у то, и посегне за пречицама, не слутећи да је то најсигурнији пут у душевни ћорсокак... Као што кажу мудри, врхунски уметници су исти као сви ми, само много бољи. Или, оно у шта гледамо није увек оно итоо видимо.

Дело човека има све атрибуте културе, пре свега из основног каузалног разлога: култура је развојни процес. Остало у вези културе је у подкатегоријама културе (подкултура, субкултура...), мерљивих очима оног другог дела људске цивилизације, које су до дана данашњег надугачко и нашироко објашњаване, препричаване и остављене, као у магли, многим појединцима на даље препричавање. Тај други део цивилизације је управо онај који се труди - због своје несавршености на релацији између срца и ума, а испред којих неуморно истурају сопствене емоције - да онима који су ту 
релацију разумели и савладали одузима драгоцено време и енергију делања.

Дело човека, надахнућем у небеској тишини лако створено, или мукотрпно кроз живот пробијајући се у свесветској буци света бескомпромисно грађено, правила нема, остаје само резултат животног напора сваког члана универзума „од протоплазме до човека”, како то пророчки преноси савременицима и будућим нараштајима ава Јустин Поповић, или како то још пророчкије беседи причајући о вредности човека васељенски двоструки доктор философије Николај Велимировић: Два страшна странца видим у себи, и ја се пробијам између ьих, гостујући час код једнога, час код другога.... Значи - пита се потом човек, носилац свеукупне културе по овоме, нисам аутентичан!? Па, ко сам ја..?

И мудри Николај наставља: Има неко у дну душе моје, кренем да га дохватим - но, видим да су ми за то потребне руке дуже од васионе. Питај Њега ко сам ја.

\section{Између светог и световног}

Као млад човек, интуитивно у себи осећајући долазеће време и покушавајући да у њему препознам, утврдим и представим колико-толико своје будуће животно битисање и умеће (које ми, желео то себи да признам или не, никако није било јасно какво је, одакле долази и у шта би требало да увире), пролазио сам кроз фазе и ситуације које су, верујем, својствене већини младих бића, претходно васпитаваних и усмераваних ка великим, или бар достојним човека, животним циљевима. Значајан опсег свеукупне људске културе уметност, и то ликовна, била ми је као бакља у тамној ноћи високо подигнута у тим жељама, надањима и очекивањима! Уметност, у најширем смислу, била ми је водиља у младости. Машта, које ми у мисаоном и сновиђачком смислу није недостајало, била ми је покретачка енергија тих дугих деценија одрастања, лутања и сазревања. Некако са стране, тих дечачких година, интуитивно осећајући динамику и лагано прилажење и стапање са све бржим социјалним, образовним, техничким и технолошким напретком свеукупне цививлизације из доба мога детињства и ране младости, нови информационо-популарни медиј - стрип - наметнуо ми се некако из прикрајка, неочекивано, али без жеље да му се одупрем. Памтим да сам веома брзо, са огромном жељом да постанем сликар, стрип прихватио из дна своје душе. Критички, радознало, али спреман „да му дам још једну шансу” да у мом дечијем универзуму маштања о будућности опстане и да га последично томе још преиспитам. Кратке и јасне поруке, истовремено ликовне и наративне, умножавале су се 
многоструко у мојој глави и водиле ме ка неким новим световима, мени до тада непредстављеним од стране званичне и официјелне педагогије и образовања, али и формалне ликовне уметности тога доба. Ипак, оно што ме је неодољиво привлачило ка стрипу, био је најчешће маестрални цртеж, вариран и понављан безброј пута увек са истим квалитетом и жаром цртача. Кратке, јасне и језгровите сцене представљене неуобичајеним цртачким и ликовним умећем, лако и брзо су ме освојиле и повеле ка новим световима које су замислили аутори.

После тих првих, тајних сусрета са делима стрипских медија, охрабрио сам себе да покушам да репродукујем неке, мени тада важне, делиће тог великог умећа нових мајстора ликовних уметности на помолу. Цртежи (наравно, и промишљени текст) који су носили епску причу о принцу Валијанту, касније Тарзану завидне душевне и физичке снаге у амбијенту афричке џунгле (машта свакога од нас уздизала се геометријском прогресијом до неслућених граница), или о детективу Рипу Кирбију, који се на умекшан начин бори у нашем времену без велике епике, били су ми довољан изазов за потајно бесомучно цртање и копирање неких сцена за које сам сматрао да их велика уметност из музеја није довољно користила, али које су уметницима-почетницима-сањарима, у које сам себе убрајао, веома важне да би напредовали и држали корак са временом у коме пребивам. Моју непоколебљиву жељу да, поред овог искорака у стрип, постанем сликар-уметник, ништа није могло да наруши. Званично, до тог доба сам се на леп, и то педагошки леп начин, упознао са сликарским делима и класике, ренесансе, модернизма, али и 20. века. Нешто касније, због критичког става који сам тада имао према сопственим вредностима, па и вредностима сопственог народа у том смислу, упознао сам се и са великим уметничким делом мога народа. „Кокетирање" са новим медијским трендовима мени је било крајње изазовно и инспиративно, поготову што сам у наредним годинама открио још краће стрипске форме, у маестралној изведби или стрип цртача, најчешће, или удружених цртача и текстописца. Породица Тарана, Јулија Џонс, касније кратке форме, али маестралне по свему, Дениса враголана, Снупија, Хогара Страшног, Дикана и још мноштва других, трајно су окупирали моју душу и срце. Касније сам откривао да су и наши значајни сликари имали „излете” у просторе стрипа и илустрације (посебно ми је занимљив Младен Јосић са својим илустрацијама о Доситеју Обрадовићу, које су нашој јавности и даље непознате). Временом, све више сам се удубљивао и у текст, без обзира што је моју главну пажњу запоседао мајсторски цртеж који је носио основну поруку и 
причу ка читаоцу и који сам до најситнијих детаља анализиpaо, критиковао, или уздизао до крајњих висина. ${ }^{3}$

Истовремено, током тих раних година и првих деценија живота, значајан део моје мистичне потребе, без које нисам могао да дишем, заокупљала је атмосфера цркви и, ређе, манастира у које бих повремено одлазио. Знам да је томе била пресудна моја склоност (и наклоност!) таквој мистичној атмосфери, као и чињеница да смо као седмогодишња деца моја сестра близнакиња и ја крштени у сеоској цркви наших родитеља (због идеолошких разлога тога времена то се није урадило у шабачкој саборној цркви), и да је свештени чин крштења обавио деда по мајци моје будуће супруге. „Деда попа”, како су га многи тада звали, ведар, насмејан и господствен, био је онај пламичак који ме је тада и још много година касније одржао у узбурканом свету мојих душевних потреба. Мистичне, мени тада још нејасне, језгровите форме света који до тада нисам познавао, указивале су ми се повремено пред очима гледајући их на иконама и нарочито на фрескама. Мистична и ванвременска атмосфера која је владала у храмовима, поготову оним са фрескописом на зидовима и сводовима, будила је у мени од раних година опијајућу смиреност и потребу да се чешће нађем у таквом амбијенту. Волео сам дуго да посматрам те слике на зидовима подељеним, као и стрип, на појединачне сцене које, уместо текстом, својом тајанственом композицијом, богатим колоритом, сугестивним погледима ликова на њима, али пре свега префињеним мистицизмом који је избијао из дубине слика право ка нама плету ону чудесну нит ка срцу и души, која се, као паукова мрежа, никако не може прекинути ни данас. Идући од сцене до сцене, временом, полако се везивала, мада још увек немушта, порука и претакала у причу све снажнијег и јаснијег значења. Исто као и код стрипа: мајсторски повезани основни градивни елементи сваку од ових „прича” лако, брзо и једноставно транспортовали су до наших емоционалних, умних и душевних потенцијала. Нема сумње, оба ова „медија”, и древна фреска, и савремени стрип, имали су заједнички темељ: архетипско порекло.

Мој млади и неразвијени дух, који је тада био у пуној потреби преиспитивања, био је, Творцу захваљујем данас за то,

3 Ово се продужило све до данашњих дана, када сам преко маестралног америчког цртача Бруса Блица својој деци, у њиховом предшколском узрасту, омогућио да се упознају и вежбају на традицији стрипског цртања своју креативност. Резултат овог вишемесечног рада са њима данас је гомила блокова које смо заједно исцртали Станко, Растко и ја током тих изузетно забавних вежби посредством телевизије упоредо са Брусом Блицем. 
МИЛЕ В. ПАЈИЋ

разапет у троуглу измећу сликарске класике, мистике медитеранско-балканског велелепног и дубоког наслеђа и примамљивих свакој новој генерацији нових искустава и трендова које време собом неумитно носи и утире пут новим хтењима човека: класична ликовна традиција, фреска и стрип су затворили овај животни троугао. Свака од ових ризница, то сам схватио много касније, архетипског је предзнака. Зато их тако лако, али свом снагом, и прихватамо. Та снага се лако може проверити на најједноставнији начин: пред фреском, као и пред стрипом, са истом снажном потребом стајаће и деца, и млади, и стари. По(р)уке ће истом снагом бити прихваћене код већине. 